\title{
Synthesis of Organometallic-based Biologically Active Compounds: In vitro Antibacteroial and Antifungal of Asymmetric Ferrocene-derived Schiff-bases Complexes
}

\author{
W. H. Hegazy ${ }^{\text {a,b }}$ and A. E.-D M. Gaafar ${ }^{\text {C }}$ \\ a Chemistry Department, College of Science, King Faisal \\ University, Al-Ahsa 31982, Saudi ${ }^{c}$ Arabia, ${ }^{b}$ Faculty of \\ Science, Suez University, Suez and Photochemistry \\ Department, National Research Centre, Giza, Egypt.
}

\begin{abstract}
A SYMMETRIC 1,1`-disubstituted ferrocene- derived Schiffbases have been prepared and used as ligands in the preparation of their novel Pd(II) and Pt(IV) metal chelates. The synthesized ligands and their metal chelates have been characterized by their physical, analytical and spectral data. These have also been used for screening against B. subtilis, S. aureus, E. coli, S. typhi (bacteria), $C$. albicans (yeast), A. niger and $F$. solani (fungi). The antimicrobial results indicated that the complexes prepared are more active than the ligand and have been found to be a novel class of organometallicbased antimicrobials.
\end{abstract}

Keywords: Ferrocene-derived Schiff bases ligands, Palladium (II) chelates, Platinum (IV) chelates and Organometallicbased antimicrobials.

Many reports ${ }^{(1-6)}$ have indicated the use of platinum and gold complexes ${ }^{(7,8)}$ of 1,1 . bis(diphenylphosphino) ferrocene against various tumors. The enhanced antibiotic activity of penicillin and cephalosporine obtained by replacing the aromatic group with the ferrocenyl moiety ${ }^{(9-11)}$ has also attracted the attention of many researchers for use of organometallics in biological sciences. Thus, the synthesis of such ferrocene derivatives allows the opening up of a potential area of research in designing and synthesizing multifunctional drugs. Schiff bases and ferrocenyl complexes have been reported ${ }^{(12-15)}$ for their coordination and antibacterial properties. Substituted ferrocene ligands and complexes were also prepared, characterized and showed their antimicrobial and anticancer activities $^{(16-22)}$. We wish to report here another class of asymmetric 1,1 disubstituted ferrocene Schiff-base derivatives and their use as ligands in the preparation of their $\mathrm{Pd}(\mathrm{II})$ and $\mathrm{Pt}(\mathrm{IV})$ metal chelates and their application as a class of organometallic-based antimicrobial agents.

${ }^{\mathrm{a}, \mathrm{b}}$ Corresponding author E-mail: whchemistry@ hotmail.com

Tel. No. +966598717176 


\section{Experimental}

\section{Materials and methods}

All solvents used were of a chromatographic grade. 1,1 '-Diacetyl-ferrocene, 2-aminopyrazine, 2-aminopyridine, 2-aminothiazole and 2-hydroxyaniline were purchased from Merck. Anhydrous Palladium (II) chloride (59\%-Merck) and anhydrous Platinum (IV) chloride (57.5\%-Merck) were used. IR, ${ }^{1} \mathrm{H}$ NMR and ${ }^{13} \mathrm{C}$ NMR spectra were recorded on Perkin Elmer 283B and $300 \mathrm{MHz}$ Varian XL300 instruments. Elemental analyses were determined at the Microanalytical Centre, Cairo University. Electronic absorptions were recorded on a Shimadzu UV240 automatic spectrophotometer in $\mathrm{CHCl}_{3}$. Conductance of the metal complexes was determined in DMF using a YSI-32 model conductometer. Magnetic measurements were done on solid complexes using the Gouy method. Melting points were recorded on a Gallenkamp apparatus and are uncorrected.

Synthesis of the ligands $\left(H L_{1}, H L_{2}\right.$ and $\left.H L_{3}\right)$

For the preparation of ligand $\mathrm{HL}_{1}$, solutions of 2-aminopyrazine $(0.47 \mathrm{~g}, 5$ mmol) in dichloromethane $\left(20 \mathrm{~cm}^{3}\right)$ and 2-aminophenol $(0.5 \mathrm{~g}, 5 \mathrm{mmol})$ in dichlormethane $\left(20 \mathrm{~cm}^{3}\right)$ were firstly mixed together and then added into a magnetically stirred solution of 1,1'-diacetylferrocene $(2.7 \mathrm{~g}, 10 \mathrm{mmol})$ in dichloromethane $\left(20 \mathrm{~cm}^{3}\right)$. The mixture was refluxed for $8 \mathrm{hr}$ under a slow stream of $\mathrm{N}_{2}$. After cooling to room temperature the solvent was evaporated to give a dark-orange solid. TLC of the crude solid showed mixture of three products, which were separated by column chromatography over silica gel using a glass column $\left(4 \times 100 \mathrm{~cm}^{2}\right)$. The first two bands were collected using dichloromethane/petroleum ether $40-60^{\circ} \mathrm{C}(80: 20)$ as eluent. One compound was characterized as symmetric 1,1'-disubstituted pyrazine-derived ferrocene (20\%) and the other was characterized as symmetric 1,1'-disubstituted phenol-derived ferrocene $(16 \%)$. The last band was collected as the desired asymmetric 1,1 disubstituted ferrocene derived Schiff-base ligand $\mathrm{HL}_{1} \quad(58 \%)$ using dichloromethane as an eluent. After removal of the solvent an orange crystalline solid was obtained, which was recrystallized from dichloromethane. Figure 1 represents the structure of the asymmetric 1,1'-distributed ferrocene-derived Schiff bases. A similar method was used for the preparation of the ligands $\mathrm{HL}_{2}$ and $\mathrm{HL}_{3}{ }^{(23)}$.

\section{Synthesis of the metal complexes}

The complexes were prepared easily and in good yield from an equimolar ratio of the ligands and the metal chloride; by the addition of $(1.0 \mathrm{mmol})$ of $\mathrm{PdCl}_{2}$ dissolved in $20 \mathrm{~cm}^{3}$ ethanol and $(1.0 \mathrm{mmol}) \mathrm{PtCl}_{4}$ dissolved in $20 \mathrm{~cm}^{3}$ acetone, to a magnetically stirred warmed $\left(40^{\circ} \mathrm{C}\right)$ solution of the ligand $(1.0 \mathrm{mmol})$ in ethanol $\left(20 \mathrm{~cm}^{3}\right)$. The mixture was refluxed for $2.5 \mathrm{hr}$. The complexes were precipitated which, upon cooling, were filtered, washed several times with ethanol, acetone and diethyl ether and then dried. 


\section{Antimicrobial studies}

Preparation of disc

The ligand/complex $(30 \mu \mathrm{g})$ in DMF $\left(0.01 \mathrm{~cm}^{3}\right)$ was mounted on a paper disc (prepared from blotting paper (5 $\mathrm{mm}$ diameter) with the help of a micropipette. The discs were left at room temperature till dryness and then applied on the microorganism-grown agar plates.

\section{Preparation of agar plates}

Minimal agar was used for the growth of specific microbial species. The preparation of agar plates for B. subtilis, S. aureus, E. coli and S. typhi (bacteria) utilized nutrient agar (2.30 g; obtained from Panreac Quimica SA, Spain) suspended in freshly distilled water $\left(100 \mathrm{~cm}^{3}\right)$ and potato dextrose agar medium (3.9 g/100 cm $\mathrm{c}^{3}$; obtained from Merck) for C. albicans (yeast), A. niger and $F$. solani (fungi). This was allowed to soak for $15 \mathrm{~min}$ and then boiled on a water bath until the agar was completely dissolved. The mixture was autoclaved for 15 min at $120^{\circ} \mathrm{C}$ and then poured into previously washed and sterilized Petri dishes and stored at $30^{\circ} \mathrm{C}$ for inoculation.

\section{Procedure of inoculation}

Inoculation was done with the help of a platinum wire loop, which was heated to red-hot in a flame, cooled and then used for the application of the microbial strains.

\section{Application of the discs}

Sterilized forceps were used for the application of paper discs to the already inoculated agar plates. The discs were then incubated at $37^{\circ} \mathrm{C}$ for $24 \mathrm{hr}$. The diameter of the zone of inhibition was measured around the disc ${ }^{(24)}$.

\section{Results and Discussion}

The synthesized ligands $\left(\mathrm{HL}_{1}, \mathrm{HL}_{2}\right.$ and $\left.\mathrm{HL}_{3}\right)$ are all soluble in dichloromethane, methanol and ethanol. Their metal complexes with Pd(II) and $\mathrm{Pt}(\mathrm{IV})$ chlorides dissolve in DMF and DMSO. All of them are amorphous solids. Molar conductance values of metal complexes (13.5-15.2 $\left.\Omega \mathrm{cm}^{2} \mathrm{~mol}^{-1}\right)$ in DMF solution show, the complexes to be nonelectrolytic ${ }^{(25)}$. Physical, spectral and analytical data of the ligands are given in Table 1.

\section{IR spectra}

The important IR frequencies of the ligands and their complexes, along with their assignments, are reported in Tables $1 \& 2$. The following observations were made from the comparison of the IR spectra of the ligands and their metal complexes.

a) The IR spectra of the ligands are almost identical to those of the metal complexes in the region $670-1550 \mathrm{~cm}^{-1}$.

b) All the ligands showed the absence of bands at about 1735 and $3420 \mathrm{~cm}^{-1}$ due to the presence of carbonyl $v(\mathrm{C}=\mathrm{O})$ and $v\left(\mathrm{NH}_{2}\right)$ stretching vibrations in the starting materials. Instead, the appearance of new bands in the spectra of 
the complexes at $1620-1625 \mathrm{~cm}^{-1}$ due to the azomethine linkage $v(\mathrm{C}=\mathrm{N})$ clearly suggested $^{(26,27)}$ the formation of the proposed Schiff-base ligands. The shifting of this azomethine band to the higher frequency side $\left(10-15 \mathrm{~cm}^{-1}\right)$ furthermore provided evidence in support of the involvement of azomethine nitrogen in coordination to the metal atom.

c) Some characteristic bands due to pyrazine, pyridine and thiazole ring shifted to higher frequency side $\left(5-10 \mathrm{~cm}^{-1}\right)$ in the spectrum of their metal complexes due to the coordination of the ligands which took place through the pyrazine, pyridine and thiazole ring nitrogen atoms to the metal atom; which supports our proposed structures.

d) A broad band at $3435 \mathrm{~cm}^{-1}$ was observed in the spectra of all the ligands due to $v(\mathrm{OH})$ group stretching vibrations. This band disappeared in all the spectra of the complexes; and a new band appeared at $1280 \mathrm{~cm}^{-1}$ due to the $v(\mathrm{C}-\mathrm{O})$ frequency, which strongly supports the observation that during chelation, deprotonation of the hydroxyl group occurred.

e) Moreover, in the far infrared region, the bands at $\sim 372$ and $\sim 466 \mathrm{~cm}^{-1}$ attributed to $v(\mathrm{M}-\mathrm{N})$ and $v(\mathrm{M}-\mathrm{O})$ were observed for all the complexes, (Table 2); these were not found in the spectra of the free ligands. However, this suggests ${ }^{(28)}$ that the hetero-aromatic ring nitrogen, azomethine nitrogen and deprotonated oxygen of the phenol moiety are all involved in the chelation process.

f) Also, weak bands at 305-309 $\mathrm{cm}^{-1}$ were found in the spectra of the Pt(IV) complexes due to the $v(\mathrm{Pt}-\mathrm{Cl})$ stretching mode. This was, however, not observable in the spectra of the Pd(II) complexes. This observation strongly suggests ${ }^{(29,30)}$ a square-planar geometry for the Pd(II) chelates (Fig. 1) and an octahedral geometry for the chelates of Pt(IV) (Fig. 2).

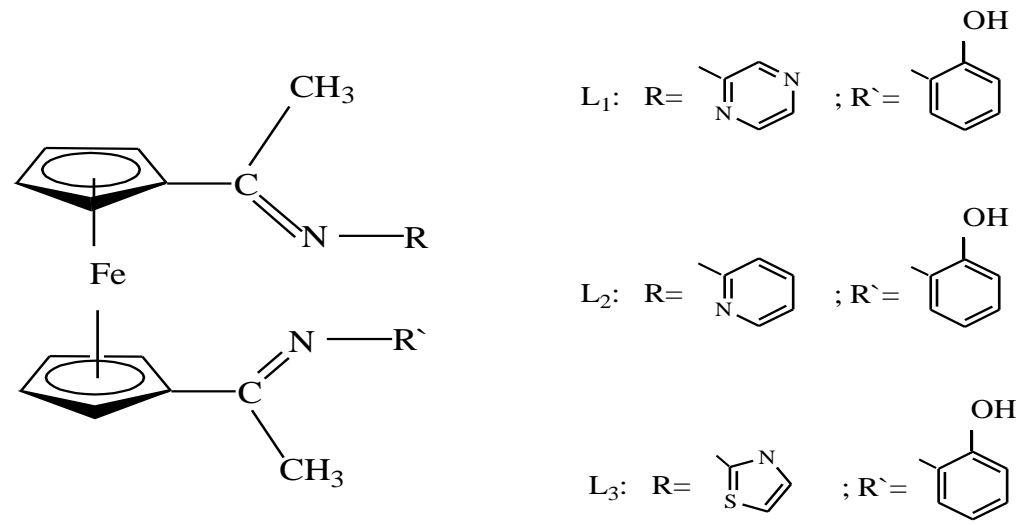

Fig. 1. Structure of the asymmetric 1, 1 -distributed ferrocene-derived Schiff bases.

Egypt. J. Chem. 55, No.3(2012) 


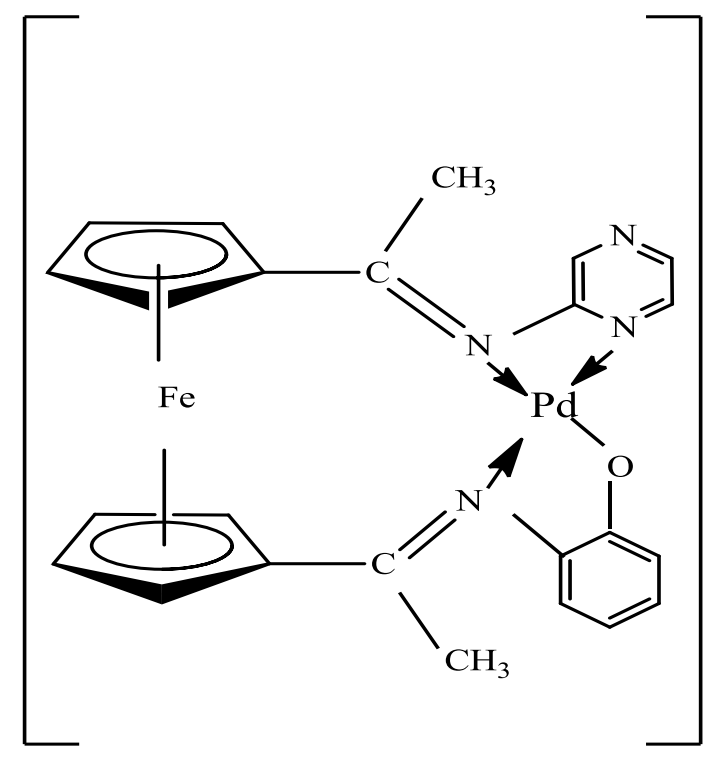

$\mathrm{Cl}$

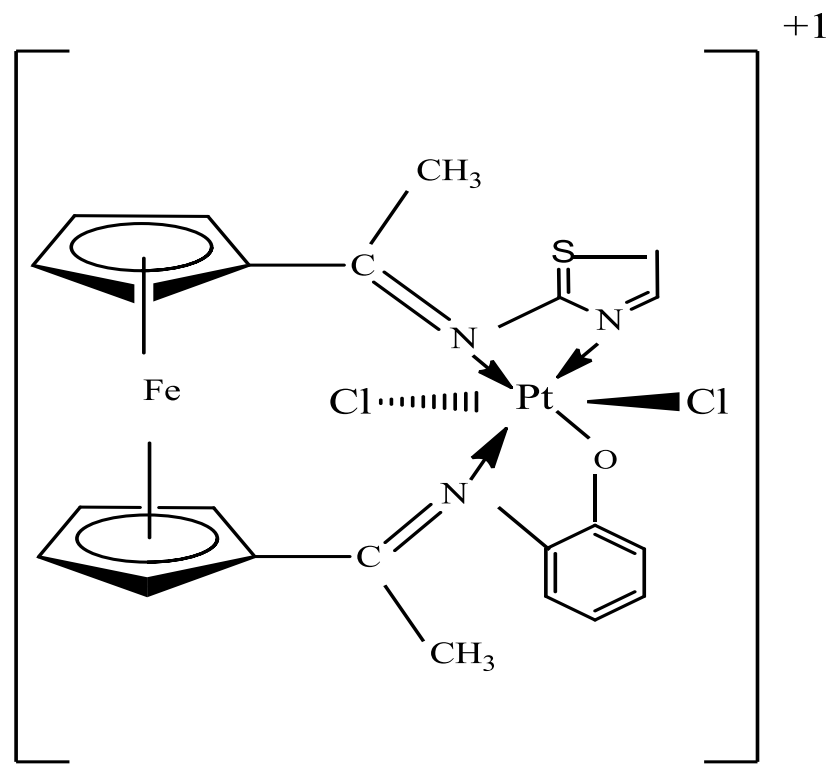

Fig. 2. Suggested structural examples for Pd (II) and octahedral Pt (IV) chelates. 


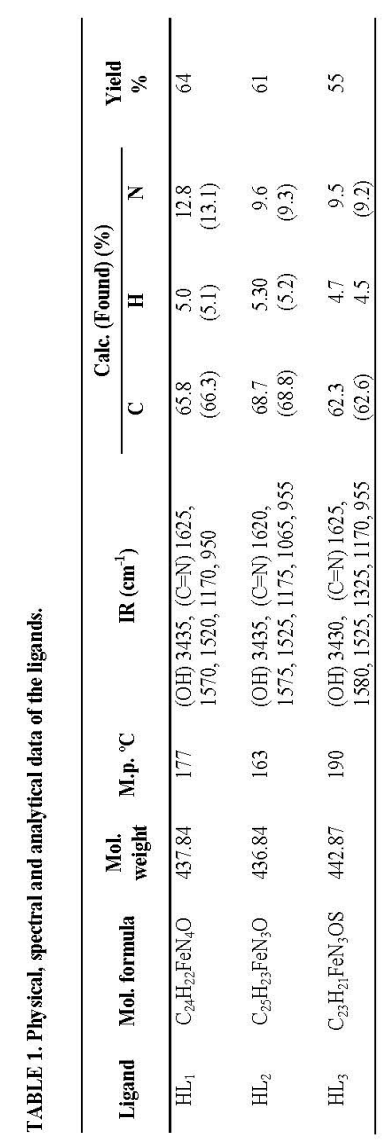

Egypt. J. Chem. 55, No.3(2012) 


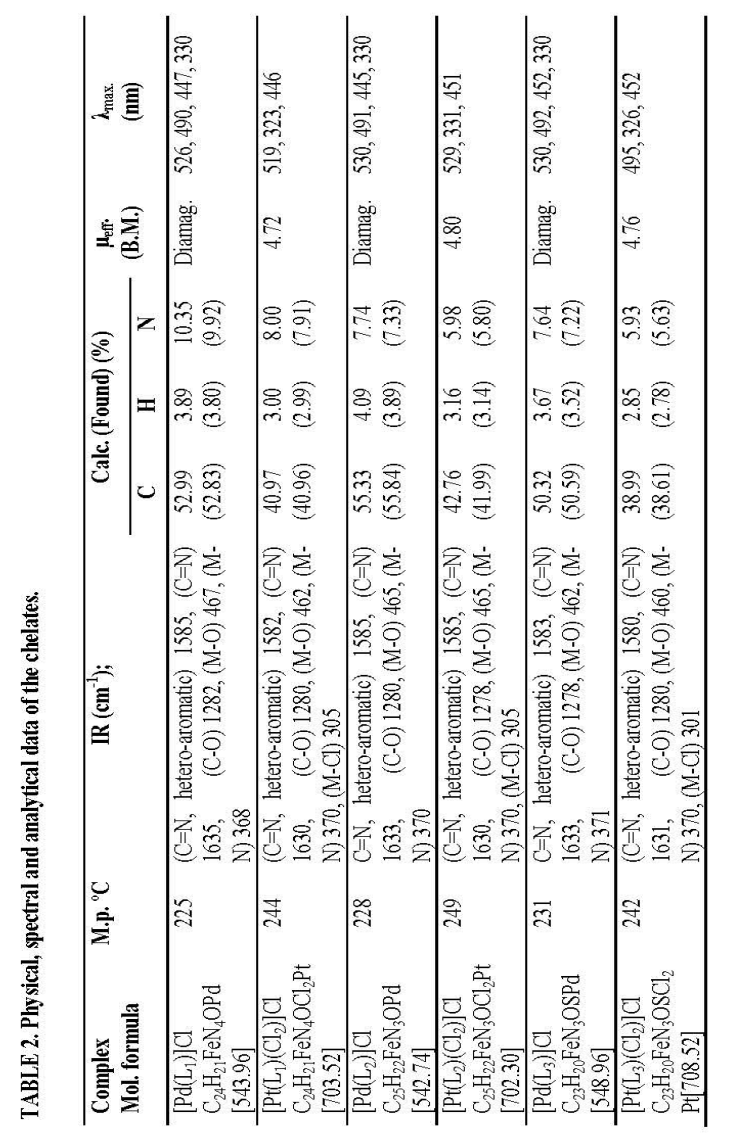

Egypt. J. Chem. 55, No.3 (2012) 
Electronic spectra

Palladium chelates showed two low energy weak bands at 526-530 nm and 490-492 $\mathrm{nm}$ and a strong high-energy band at $330 \mathrm{~nm}$. These are assigned to ${ }^{3} \mathrm{~A}_{2 \mathrm{~g}}(\mathrm{~F}) \rightarrow{ }^{3} \mathrm{~T}_{2 \mathrm{~g}}(\mathrm{~F}),{ }^{3} \mathrm{~A}_{2 \mathrm{~g}}(\mathrm{~F}) \rightarrow{ }^{3} \mathrm{~T}_{1 \mathrm{~g}}(\mathrm{~F})$ and ${ }^{3} \mathrm{~A}_{2 \mathrm{~g}}(\mathrm{~F}) \rightarrow{ }^{3} \mathrm{~T}_{2 \mathrm{~g}}(\mathrm{P})$ transitions. The low energy bands are expected for square planar configuration. The strong highenergy band, in turns, is assigned to metal-ligand charge transfer.

The electronic spectra of Pt(IV) chelates consist of one broad low energy bands at 495-529 nm which is characteristic to high-spin octahedral geometry of $\mathrm{Pt}(\mathrm{IV})$ complexes. One strong high-energy band at $323-331 \mathrm{~nm}$ is also observed, assigned to metal-ligand charge transfer. These are assigned to ${ }^{5} \mathrm{E} 1 \mathrm{~g}$ (D) $\rightarrow{ }^{5} \mathrm{~b}_{1 \mathrm{~g}}$ (D) transitions.

A weak broad band was also observed for every complex at 445-452 $\mathrm{nm}$. This band is assigned to transition ${ }^{1} \mathrm{~A}_{1 \mathrm{~g}} \rightarrow{ }^{1} \mathrm{E}_{1 \mathrm{~g}}$ in the iron atom of the ferrocenyl group, which indicates that there is no magnetic interaction between $\mathrm{Pd}(\mathrm{II})$ and $\mathrm{Pt}(\mathrm{IV})$ ions and $\mathrm{Fe}(\mathrm{II})$ ion of the ferrocenyl group ${ }^{(30)}$.

At room temperature the magnetic moments ' $\mu_{\text {eff }}$ ' given in Table 2 are supporting the results of the electronic spectra.

${ }^{1} H$ NMR and ${ }^{13} C$ NMR spectra

The ${ }^{1} \mathrm{H}$ NMR and ${ }^{13} \mathrm{C}$ NMR spectra of the free ligands and their metal chelates were taken in DMSO- $d_{6}$. The ${ }^{1} \mathrm{H}$ NMR spectral data are reported along with possible assignments in Table 3 . The ligand displays signals at $\delta 2.3$ 2.4(methyl group), 4.1-4.7 (-ferrocenyl), $6.5(-\mathrm{CH}=\mathrm{N}), 6.8-7.9$ (aromatic), 8.3-8.9 (hetero-aromatic) and $9.6 \mathrm{ppm}$ (-OH disappeared after $\mathrm{D}_{2} \mathrm{O}$ exchange). The protons due to aromatic and hetero-aromatic groups (pyrazine, pyridine and thiazole rings) were found in their expected regions ${ }^{(31)}$. The conclusions drawn from these studies lend further support to the mode of bonding discussed above. The presence of the phenolic $(\mathrm{OH})$ protons at $\delta 9.6 \mathrm{ppm}$ that vanished in the spectra of the metal complexes suggested deprotonation and subsequent participation in complexation. The protons due to the ferrocenyl moiety were also found in the same region as expected and reported ${ }^{(32)}$ earlier. In the spectra of their metal chelates, these protons shifted toward more low field due to the participation of the shielding electrons in complex formation and subsequently turn those protons excitation values to more deshielding and moreover the complexation increases conjugation and coordination to the metal atoms. The signals due to azomethine protons also shifted downfield compared with the corresponding ligand signals, indicating coordination of the ligand via the azomethine nitrogen due to participation of the free lone pair of electron of nitrogen atom in covalent - coordinate complex bond. This electron when withdraw to make the complex bond induces more deshielding effect on the azomethine protons. The number of protons of various groups, calculated from the integrations, matches the assumption of complex formation as illustrated in Fig. 2.

Egypt. J. Chem. 55, No.3(2012) 


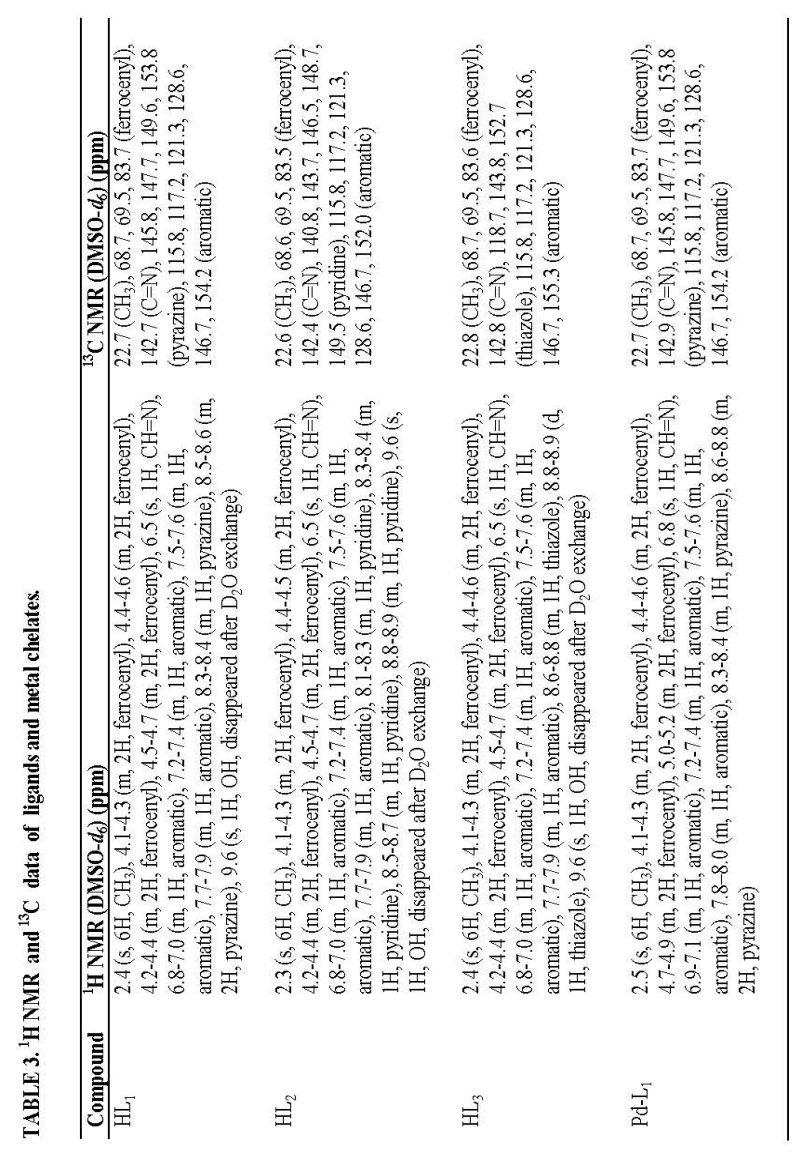

Egypt. J. Chem. 55, No.3 (2012) 


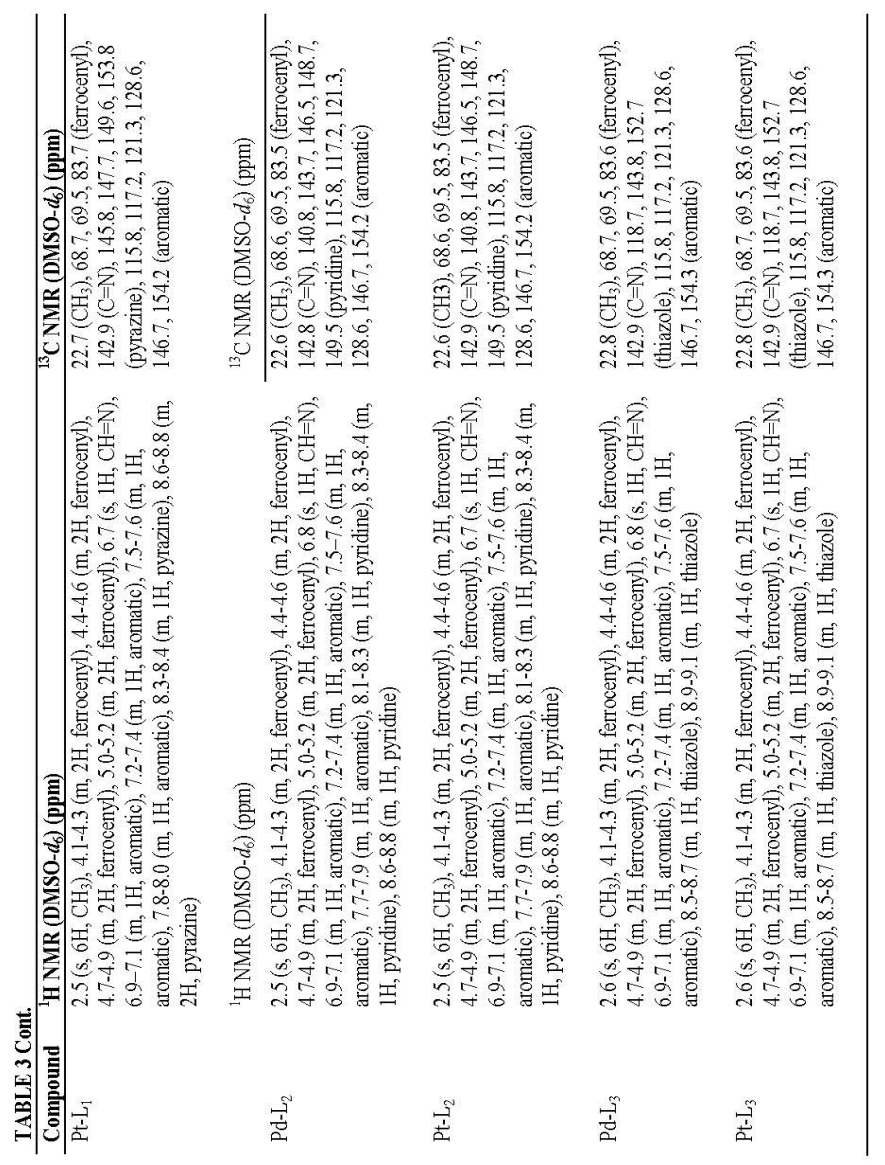

Egypt. J. Chem. 55, No.3(2012) 
In the ${ }^{13} \mathrm{C}$ NMR spectra, the ligand displays signals at $\delta 22.6-22.8\left(-\mathrm{CH}_{3}\right)$, 68.6-83.7 (ferrocenyl), 142.4-142.7 $(\mathrm{C}=\mathrm{N}), 142.4-153.7$ (hetero-aromatic), 115.8146.7 (aromatic) and 152.0-155.0 ( $\left.\mathrm{sp}^{2} \mathrm{C}-\mathrm{O}\right)$ carbon atoms. The signals appeared at ca $83.6 \mathrm{ppm}$ are due to the quaternary carbon (position 1) on the cyclopentadienyl ring. Signals appeared at ca. 149.5-153.8 for the heteroaromatic rings are due to quaternary carbons. On complexation, all signals appear downfield in comparison ${ }^{(33)}$ with the corresponding signals of the ligand, indicating coordination and complexation with the central metal atom. It was observed that DMSO did not have any coordinating effect on either the spectra of the ligands or on their complexes.

\section{Antimicrobial properties}

The title ligands and their metal complexes were evaluated for their antimicrobial activity against B. subtilis, S. aureus, E. coli, S. typhi (bacterium), $C$. albicans (yeast), A. niger and $F$. solani (fungi). The compounds were tested at a concentration of $30 \mu \mathrm{g} / 0.01 \mathrm{~cm}^{3}$ in DMF solution using the paper disc diffusion method devised and reported earlier ${ }^{(34,35)}$. The results of these studies, reproduced in Table 4, indicate that both the Schiff-base ligands and their metal complexes showed variable activity against one or more bacterial strains. In comparison with the ligands, the metal complexes were found to be more antimicrobial active. It is known that, compared with the parent Schiff bases, chelation tends to make the ligands act as more powerful and potent bactericidal agents, thus killing the microorganisms. A possible explanation is that, in the chelated complex, the positive charge of the metal is partially shared with the donor atoms present in the ligands and there is $\pi$-electron delocalization over the whole chelate ring ${ }^{(35,36)}$. This, in turn, increases the lipophilic character of the metal chelate and favours its permeation through the lipoid layers of the microorganism membranes. Apart from this, other factors, such as solubility, conductivity and dipole moment justified (influenced by the presence of metal ions), may also be the possible reasons for increasing this activity ${ }^{(35,36)}$.

TABLE 4. Antimicrobial activity data for the ligand and its chelates*

\begin{tabular}{lccccccc}
\hline $\begin{array}{l}\text { Ligands / } \\
\text { complexes }\end{array}$ & B. subtilis & S. aureus & E. coli & S. typhi & C.albicans & A. niger & F. solani \\
\hline $\mathrm{HL}_{1}$ & + & ++ & ++ & + & + & + & + \\
$\mathrm{Pd}_{\mathrm{L}}$ & +++ & +++ & +++ & ++ & ++ & ++ & ++ \\
$\mathrm{Pt}-\mathrm{L}_{1}$ & ++++ & +++ & +++ & +++ & ++ & ++ & ++++ \\
\hline $\mathrm{HL}$ & + & + & ++ & + & - & + & ++ \\
$\mathrm{Pd}-\mathrm{L}_{2}$ & +++ & ++ & +++ & +++ & ++ & ++ & ++++ \\
$\mathrm{Pt}-\mathrm{L}_{2}$ & ++++ & ++++ & ++++ & +++ & +++ & +++ & ++++ \\
\hline $\mathrm{HL}$ & + & + & ++ & ++ & - & + & + \\
$\mathrm{Pd}_{3}-\mathrm{L}_{3}$ & +++ & +++ & +++ & +++ & ++ & ++ & +++ \\
$\mathrm{Pt}-\mathrm{L}_{3}$ & +++ & +++ & +++ & ++++ & ++++ & +++ & +++ \\
\hline
\end{tabular}

* Inhibition zone diameter mm (\% inhibition): +, 6-10 (27-45\%); ++, 10-14 (45-64\%); +++, 14-18 $(64-82 \%)$; ++++, 18-22 (82-100\%). Percent inhibition values are relative to inhibition zone $(22 \mathrm{~mm})$ of the most active compound with $100 \%$ inhibition. 


\section{References}

1. Xiaoxian, Z., Youngmin, L., Fajun, N. and Yongxiang, M., Polyhedron, 11, 447 (1992).

2. Singh, S.P. and Singh, N.B., Polyhedron, 9, 557 (1990).

3. Gang, G., Feng, L., Jishan, X. and Yongxiang, M., Polyhedron, 7, 303 (1988).

4. Patil, S.R., Kantak, U.N. and Sen, D.N., Inorg.Chim. Acta, 68, 1 (1983).

5. Patil, S.R., Kantak, U.N. and Sen, D.N., Inorg. Chim. Acta, 63, 261 (1982).

6. Iami, H. and Ota, T., Bull. Chem. Soc. Jpn, 47, 2497 (1974).

7. Longato, B., Pilloni, G., Valle, G. and Gorain, B., Inorg. Chem. 27, 956 (1988).

8. Hill, D.T., Girard, G.R., McCabe, E.L., Johnson, R.K., Stupik, P.D., Zhang, J.H., Reiff, W.M. and Eggleston, D.S., Inorg. Chem. 28, 3529 (1989).

9. Edwards, E.I., Epton, R. and Marr, G., J. Organomet. Chem. 85, C-23 (1975).

10. Rockett, B.W. and Marr, G., J. Organomet. Chem. 123, 205 (1976).

11. Houlton, A., Dilworth, J.R., Roberts, R.M.G., Silver, J. and Drew, M.B., Polyhedron, 9, 2751 (1990).

12. Issa, Y.M. and Hegazy, W.H., Synth. React. Inorg. Met-Org. Nano-Met. Chem. 31, 303 (2001).

13. Hegazy,W.H., Monats. Chemie, 132, 639 (2001).

14. Abd-Elzaher, M.M., Hegazy, W.H. and Gaafar, A. El-Din, M., Appl. Organometal. Chem. 19, 911 (2005).

15. Hegazy, W.H. and Al-Motawaa, I.H., Bioinorg. Chem. Appl. doi:10.1155, 531946 (2011).

16. Henderson, W. and Alley, S.R., Inorg. Chem. Acta, 322,101 (2001).

17. Abd-Elzaher, M.M., Appl.Organometal. Chem. 18, 149 (2004).

18. Chohan, Z.H., Appl. Organometal.Chem. 20, 112 (2006).

19. Abd-Elzaher, M.M. and Ali, I.A., Appl. Organometal. Chem. 20, 107 (2006).

20. El-Shiekh, S.M., Abd-Elzaher, M.M. and Eweis, M., Appl. Organometal. Chem. 20, 505 (2006).

21. Abd-Elzaher, M.M., El-Shiekh, S.M. and Eweis, M., Appl. Organometal. Chem. 20,597 (2006).

Egypt. J. Chem. 55, No.3(2012) 
22. Abd-Elzaher, M.M., Mostafa, S.A., Labib, A.A. and Ali, M.M., Monatsh. Chemie, 141, 387 (2010).

23. Chohan, Z.H. and Praveen, M., Appl. Organometal. Chem. 15, 617 (2001).

24. Abd-Elzaher, M.M., Appl. Organometal. Chem. 18,149 (2004).

25. Geary, W.J., Coord. Chem. Rev. 7, 81 (1971).

26. Yong-xiang, M., Zheng-zhi Z., Yun, M. and Gang, Z., Inorg. Chim. Acta. 165, 185 (1989).

27. Nakamoto, K., Infrared Spectra of Inorganic and Coordination Compounds, $2^{\text {nd }} \mathrm{Ed}$. Wiley Interscience: New York (1970).

28. Agarwal, R.K., J. Indian Chem. Soc., 65, 448 (1988).

29. Bellamy, L.J., The Infrared Spectra of Complex Molecules. John Wiley: New York (1971).

30. Ferrero, J.R., Low-Frequency Vibrations of Inorganic and Coordination Compounds. John Wiley: New York (1971).

31. Chohan, Z.H. and Praveen, M., Met-Based Drugs, 6, 149 (1999).

32. Scowen, I.J., Davies, J.E. and Halcrow, M.A., J. Chem. Soc. Dalton. Trans. 3791 (1998).

33. Williams, D.H. and Fleming, I., Spectroscopic Methods in Organic Chemistry. McGraw-Hill: London (1989).

34. Chohan, Z.H. and Sherazi, S.K.A., Synth. React. Inorg. Met-Org. Nano-Met. Chem. 29, 105 (1999).

35. Chohan, Z.H. and Kausar, S., Met-Based Drugs, 7, 17 (2000).

36. Chohan, Z.H. and Farooq, M.A., Synth.React. Inorg. Met-Org. Nano-Met. Chem. 31, 1853 (2001).

(Received 25/7/2012; accepted 31/10/2012) 


\section{تثييا مركبات عضو-معدنية ذات نشاط بيولوجى كمضادات بكتيرية

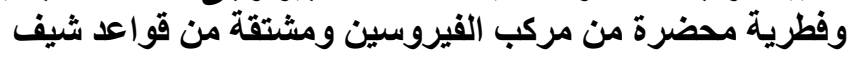

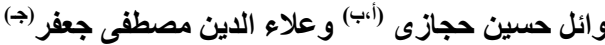

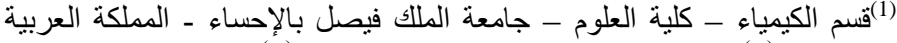

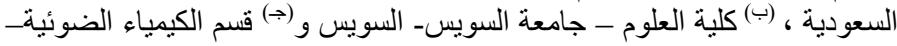

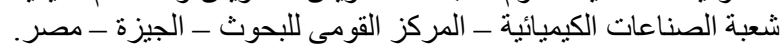

إن المركبات غير المتماثلة ثنائية استبدال الفيروسين والمشتقة من قو اعد شيف قد

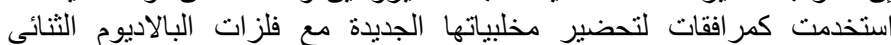

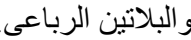

تم توصيف المر افقات المحضرة ومخلبياتها بدقة من خلال معطياتها الفيزيائية

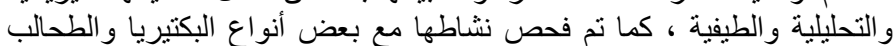

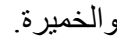

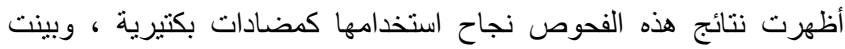

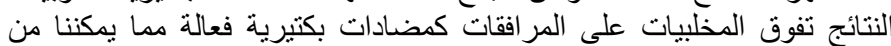

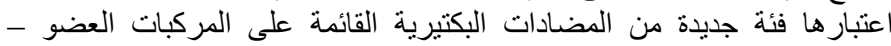
معدنية. 